Author: MC Marumoagae

DO BOARDS OF TRUSTEES OF SOUTH AFRICAN RETIREMENT FUNDS OWE FIDUCIARY DUTIES TO BOTH THE FUNDS AND FUND MEMBERS? THE DEBATE CONTINUES

2012 VOLUME 15 No 2 


\section{DO BOARDS OF TRUSTEES OF SOUTH AFRICAN RETIREMENT FUNDS OWE FIDUCIARY DUTIES TO BOTH THE FUNDS AND FUND MEMBERS? THE DEBATE CONTINUES}

\section{Marumoagae*}

\section{$1 \quad$ Introduction}

Section 7C(2) of the Pensions Fund Act 24 of 1956 (hereinafter referred to as the 'PFA') outlines the general duties of the boards of retirement funds. Over the years there has been much debate in the retirement fund industry as to to whom the board, as the managing body of the retirement fund, is accountable. ${ }^{1}$ However, South African courts and tribunals adjudicating pension fund-related disputes and the retirement industry at large seem to share the view that the board of trustees is accountable to both the fund and its members, ${ }^{2}$ meaning that the board is required to act in the best interest of the fund and its members. Section $7 C(2)(a)$ of the PFA provides that

in pursuing its object the board shall- take all reasonable steps to ensure that the interests of members in terms of the rules of the fund and the provisions of this Act are protected at all times, ...

I will argue in this paper that the statutory obligation for the board to act in the best interest of the members does not in itself entail that the board is accountable to the

Motseotsile Clement Marumoagae. LLB (WITS), LLM (NWU), LLM (WITS), Certificate in Advanced Broadcasting Law (Mandela Institute/WITS). Candidate Attorney, Benoni Justice Centre, Legal Aid South Africa, djdialogue@gmail.com.

1 Mahlangu $v$ Soweto City Council Pension Fund Case No PFA/GA/9384/2006/SM para 28, where it was held that "it is clear that a fund has fiduciary duties towards its members and beneficiaries. This fiduciary obligation arises from the fact that it is entrusted with the control of property with which it is bound to manage for the benefit of others". See also Isaacs v SAMA Pension Fund Case No PFA/WE/278/98/NJ para 13, where it was said that the board of trustees owes fiduciary duties to both the fund and its members. See also Tex Corporation Provident Fund $v$ Lorentz 19994 SA 884 (SCA) para 15 and Marais v Momentum Life Pension Fund Case No PFA/GA/1459/01/CN 2002 para 26, where the adjudicator went as far as saying that the board must "...at all times act in the best interest of the fund, its members and other beneficiaries. They are furthermore required to act impartially towards the various stakeholders in a fund". 
members of the pension fund, nor does that entail that the board owes a fiduciary duty to the members of the fund. The purpose of this paper is to demonstrate that the board of trustees of a South African pension fund is accountable to and owes fiduciary duties only to the fund it serves and not to members of the fund. I will also argue that a fiduciary duty arises in the context of a fiduciary relationship, which relationship is based on the principle of loyalty. Furthermore, I will argue that at the very best the board owes a duty of good faith towards the members of the fund. This will be done by distinguishing the legal position relating to trust law from the law relating to retirement funds in South Africa.

\section{$2 \quad$ Best interest of members}

Most established employers set up retirement funds consisting of money contributed by them and their employees to provide pension fund benefits on retirement as part of those employees' employment benefits. ${ }^{3}$ These can be in the form of defined contribution schemes or defined benefit arrangements. ${ }^{4}$ The employer's retirement savings plan in the form of a retirement fund is an essential part of an employee's future financial security. However, the fact that the employer establishes or even negotiates a retirement fund does not entail that the employer administers and controls such a scheme. ${ }^{5}$ Once established, the retirement fund concerned must

3 Sanlam 2012 southafrica.smetoolkit.org. See also George Analysis of South African Pension Fund Conversions 6.

4 See Registrar of Pension Funds v ICS Pension Fund 2010 ZASCA 63 para 14, where it was stated that "there are two kinds of pension funds (at least for present purposes). One is a 'defined benefit fund'. In such a fund members become entitled to fixed benefits that are circumscribed by the rules, irrespective of the performance of the investments that are made by the fund. If the investments of the fund produce insufficient income to meet those obligations then the employer underwrites the shortfall. If the investments that are made by the fund perform better than expected a surplus will accrue to the fund. The other is a 'defined contribution fund'. In such a fund the benefits that are payable to members are directly linked to the performance of the investments that are made by the fund. If the investments perform well then the benefit will accrue to members directly and they will likewise bear the brunt of poor performance. Such a fund thus relieves the employer of the risk of poor performance of its investments and likewise promises to members the direct benefit of sound performance".

5 Section 7C(1) Pensions Fund Act 24 of 1956 (PFA) provides that "the object of a board shall be to direct, control and oversee the operations of a fund in accordance with the applicable laws and the rules of the fund". This essentially means that all of the stakeholders, including unions, members and employers, are enjoined to appreciate that retirement funds are separate and independent entities which ought to be managed and controlled independently by a board of $555 / 569$ 
have an independent 'managing body' which will ensure that the fund operates smoothly and is able to achieve the aims and objectives for which it was created. In terms of section $7 \mathrm{~A}$ of the Act

...every fund shall have a board consisting of at least four board members, at least $50 \%$ of whom the members of the fund shall have the right to elect.

The board of trustees is the managing and controlling body of the fund and should operate independently of the employer, members and other stakeholders of the fund. ${ }^{6}$ The board of trustees should also carry out its duties as mandated by the rules of the fund and the Act. It has been argued - correctly in my view - that ${ }^{7}$ :

a retirement fund is not simply a vehicle through which an employer provides retirement benefits agreed with its employees. If that were the case, it would not be necessary to have trustees of the fund.

The board of trustees is not constituted to rubber stamp the wishes of either the employer contributing to the fund or the members of the fund; it is also not obliged to act in accordance with such wishes. Instead, the board should be in a position to manage the affairs of the fund in a manner that advances the interests of the fund.

The PFA requires the board in pursuing its objects to take all reasonable steps to ensure that the interests of members in terms of the rules of the fund and the provisions of this Act are protected at all times. ${ }^{8}$ I submit that this does not entail that the board has to go out of its way to seek to ensure that members' wishes are carried out, but merely to ensure that when it carries out its duties towards the fund, the members are not unjustly prejudiced. It has been argued, correctly in my view, that section $7 \mathrm{C}(2)$ of the PFA does not require the board to seek to advance the best interest of members but only to

trustees. When carrying out its duties the board of trustees should be able to implement the mandate of the fund free from the outside influence of other stakeholders of the fund.

6 Section 7C(1) PFA provides that "the object of a board shall be to direct, control and oversee the operations of a fund in accordance with the applicable laws and the rules of the fund".

7 Asher 2001 SAAJ 6.

8 Section 7C(2)(a) PFA. 
take all reasonable steps to protect the interest of members as reflected in terms of the rules of the fund and the provisions of the PFA. ${ }^{9}$

Further, at the very least the board owes a duty of good faith towards the members and other stakeholders in the fund. ${ }^{10}$

In ensuring that the board acts in good faith towards the members, the PFA mandates the board among other things to

ensure that adequate and appropriate information is communicated to the members of the fund by informing them of their rights, benefits and duties in terms of the rules of the fund. ${ }^{1}$

Information regarding the contribution of payments, the benefits payable, the fund's investment performance and the eligibility of certain benefits should as soon as practicable be made available to the members. ${ }^{12}$ This is in line with section 7D(c) of the PFA, which provides that

the duties of a board shall be to ensure that adequate and appropriate information is communicated to the members of the fund informing them of their rights, benefits and duties in terms of the rules of the fund.

In terms of the rules of the fund the board has a responsibility to ensure that benefits payable are paid promptly and timeously, unless there is a legitimate reason occasioning the delay or refusal to pay.

It is important to point out that South African retirement funds in terms of section $4 \mathrm{~B}(1)$ of the PFA are juristic persons. ${ }^{13}$ In terms of section $5(1)(\mathrm{a})$ of the PFA, once registered a fund shall in so far as its activities are concerned, become a body corporate capable of suing and being sued in its corporate name and of doing all such things as may be necessary for or incidental to the exercise of its powers or the performance of its functions in terms of its rules. As such, the fund is capable of

9 Hunter 2000 www.hunterlaw.co.za 11.

10 Hunter et al Pension Funds Act 171.

11 Section 7D(c) PFA.

12 Liberty Corporate 2009 www.libertycorporate.co.za.

13 See also Vivian "South African Insurance Markets" 689. 557 / 569 
acquiring its own legal identity through the registration of a set of rules under the PFA. Pension funds are capable of acquiring and owning their own assets as separate legal persons to the exclusion of all others. ${ }^{14}$ Contributions made by employers and employees for the future benefit of the members, once made, become assets of the fund and the members will be entitled to them only in accordance with the rules of the fund.

The members can also forfeit such benefits if the prescribed time limits, procedures and formalities provided for in the rules of the fund are not adhered to. ${ }^{15}$ Therefore the members cannot dictate how the fund should be run in order to safeguard their interests. However, as stakeholders in the fund they need to be adequately informed about their benefits plan and how their investments are run by the board of trustees. They are entitled to be satisfied that the fund is being properly run and managed. ${ }^{16}$ By so satisfying them the board of trustees would be acting in good faith towards them.

The concept of 'fiduciary duty' has not been precisely defined in South Africa and has often 'wrongly' been used interchangeably with the concept of 'good faith' by our courts and academics. ${ }^{17}$ In her attempt to distinguish the said concepts, Hunter argues correctly in my view that: ${ }^{18}$

14 Andrews 2004 SAAJ 6.

15 For instance contributions should be made regularly as provided for in the rules. As far as disability benefits are concerned, the prescribed procedures and time limits should be followed. Most pension funds rules provide the trustees with the discretion to decide whether a member is entitled to disability benefit or not.

16 See UK Court of Appeal in McDonald v Horn 19951 All ER 961 (CA) as quoted in Hunter et al Pension Funds Act 165.

17 Ferguson $v$ Sapref Pension Fund Case No PFA/WE/673/99/SM para 9, where it was held that "The duty to act in good faith therefore does not equate to a duty to act reasonably ..., and it is not a fiduciary duty..." The duty of the board of trustees to act in good faith towards stakeholders in the fund such as members emanates from s2(a) Financial Institutions (Protection of Funds) Act 28 of 2001, which provides that "a director, member, partner, official, employee or agent of a financial institution or of a nominee company who invests, holds, keeps in safe custody, controls, administers or alienates any funds of the financial institution or any trust property- must, with regard to such funds, observe the utmost good faith and exercise proper care and diligence; ..." In order to discharge its duty of good faith to the members of the fund, the board of trustees might among other things be required to provide members with information which is necessary to safeguard their interests in the fund. See Caffin v African Oxygen Limited Pension Fund Case No PFA/WE/14/98 \& PFA/WE/26/98 para 14, where it was held that "it would seem to be just and equitable, therefore, that boards of trustees be obliged in terms of their duty to act in good faith to disclose such information as would reasonably enable members of pension funds to consider the 
a duty of good faith requires its bearer to exercise its powers for the purposes for which they were conferred on it and not for any other purpose.... A fiduciary duty imposes upon its bearer a duty to act in the best interest of the person or persons to whom the duty is owed.

The board of trustees demonstrates only good faith towards the members of the fund by keeping them informed of the interests they have in the fund and also by ensuring that members are not prejudiced when the board is performing its functions.

\section{The fiduciary duties of the board}

Common law fiduciary duties have been developed over time by our courts. ${ }^{19}$ There are also fiduciary duties which have been established through legislation. ${ }^{20}$ Fiduciary duties arise as a consequence of a fiduciary relationship existing between the board and the fund. The board of trustees occupies a fiduciary position and holds the assets of the fund in a fiduciary capacity. ${ }^{21}$

The existence of such a duty and its nature and extent are questions of fact to be adduced from a thorough consideration of the substance of the relationship and any relevant circumstances which affect the operation of that relationship ... ${ }^{22}$

It is worth noting, however, that the concept of a fiduciary duty has proven to be somewhat challenging for South African courts and academics, a fact which has led to this concept being referred to as a concept with 'no clearly defined meaning'. ${ }^{23}$

consequences that the information held for them in the realisation of their rights, interests and expectations. The failure to furnish such information, without appropriate justification, will constitute an improper exercise of the board's powers and will amount to maladministration of the fund as contemplated in the definition of a complaint in section 1 of the Pension Funds Act".

18 Hunter 2000 www.hunterlaw.co.za fn 25.

19 Ikard 2006 privateaudio.homestead.com para 2. See also Transvaal Cold Storage Co Ltd $v$ Palmer 1904 TS 4, Robinson v Randfontein Estates Gold Mining Co Ltd 21921 AD 168, Hofer v Kevitt 19962 SA 402 (C) 407B, Phillips v Fieldstone Africa (Pty) Ltd 20041 All SA 150 (SCA), Volvo (Southern Africa) (Pty) Ltd v Yssel 20096 SA 531 (SCA).

20 See among others s 76 Companies Act 71 of 2008, s 9 Trust Property Control Act 57 of 1988, s 7C Pension Funds Act 24 of 1956 and s 2(a) Financial Institutions (Protection of Funds) Act 28 of 2001.

21 Du Toit 2007 Stell LR 471.

22 Bellairs v Hodnett 19781 SA 1109 (A) 1130F. See also Phillips v Fieldstone Africa (Pty) Ltd 2004 1 All SA 150 (SCA) para 27.

23 Hofer v Kevitt 19962 SA 402 (C) 407B. See also Du Toit 2007 Stell LR 471. 
For the purposes of this paper, fiduciary duties should be understood as the obligation and responsibility the board of trustees has to be loyal to the fund, and thereby to carry out its duties towards the fund with dignity and honesty in order to advance the objectives of the fund. It has been convincingly argued that: ${ }^{24}$

the principal feature of a fiduciary duty is the duty of loyalty by the fiduciary to his or her principal. This duty means that the fiduciary must act in utmost good faith and in accordance with the powers properly conferred on him or her, must exercise loyalty towards the fund, to the exclusion of all others....

I submit therefore that the boards of trustee of pension funds owe fiduciary duties only to the funds they serve and not to the members of such funds. They owe a duty of loyalty only to the fund to the exclusion of all other stakeholders of the fund, including the members of those funds.

The board of trustees' fiduciary duties include among others the duty to exercise the ordinary skill, care, diligence and prudence necessary to achieve the objectives of the fund ${ }^{25}$ the duty to perform the functions of the fund in such a way that all of the stakeholders of the fund are not prejudiced, especially members of the fund ${ }^{26}$ the duty to be loyal only to the fund; the duty to preserve the assets of the fund and also to ensure that the information relating to the fund is kept confidential unless it is necessary to reveal such information; the duty to manage the fund effectively and efficiently by keeping accurate books and records; the duty to uphold and defend the fund and its assets as well as to carry out the obligations of the fund, such as paying benefits to members; the duty to avoid conflict of interest between the affairs of individual members of the board and those of the fund; as well as the duty to utilise expertise outside the board in areas where the board lacks such expertise for the proper functioning of the fund. ${ }^{27}$

24 Hunter et al Pension Funds Act 172.

25 Section 7C(2)(b) PFA.

26 Section 7C(2)(a) PFA.

27 Section 7C(2)(E) PFA. 
It has been consistently stated in the South African retirement industry that the board of trustees is required to act in the best interests of the fund and its members; that it owes a fiduciary duty to both the fund and its members. ${ }^{28}$ Such a view by our courts is generally accepted as correct and its justification seems to be in section $7 \mathrm{C}(2)(\mathrm{a})$ of the PFA. ${ }^{29}$ It was held in Johannesburg Municipality Pension Fund $v$ NCB Employee Benefits (Pty) $L t d^{30}$ that:

what is plain from the provisions of the Act and a rule ... is that the committee of the fund ... occupies a position of trust. It has a fiduciary duty towards the members of the fund on whose behalf the assets of the pension funds are administered.

Such a position emanates from the fact that initially retirement funds in South Africa were established as trusts. As a result the principles relating to trust law are applied as they are to retirement funds, without distinguishing between trust law and pension law. I am of the view that such an approach is wrong.

It has been argued correctly in my view that: $:^{31}$

many trust law principles cannot properly be applied to the relationship between boards and members of funds because trusts and retirement funds are fundamentally different.

A trust has been defined as: $:^{32}$

a legal institution in which a person, the trustee, subject to public supervision, holds or administers property separately from his or her own, for the benefit of another person or persons or for the furtherance of a charitable or other purpose.

28 See Tex Corporation Provident Fund v Lorentz 19994 SA 884 (SCA) para 15. See also Cheadle, Thompson and Haysom Attorneys Date Unknown www.naledi.org.za para 18, where it is argued that "trustees are under a duty to utilise their powers for the benefit of and in the exclusive interest of the fund and its members. Whenever there is a divergence between the funds' interests and those of the service provider the legal duty of trustees is clear, they are obliged to act in the interests of the fund and its members".

29 This section provides that "in pursuing its object the board shall- take all reasonable steps to ensure that the interests of members in terms of the rules of the fund and the provisions of this Act are protected at all times ..."

30 Johannesburg Municipality Pension Fund v NCB Employee Benefits (Pty) Ltd (Unpublished case) Case No 74/01 as quoted in Hunter et al Pension Funds Act 161, as well as the list of cases referred to thereon.

31 Hunter et al Pension Funds Act 163.

32 Cameron et al South African Law of Trusts 1. 
It is worth noting that under South African trust law, a trust is not a legal persona and the assets of the trust vest in its trustees in their capacities as trustees. ${ }^{33}$ Under South African law trusts do not have separate legal personality, save where a statute provides otherwise. $^{34}$

The essence of a trust is that the trustees hold the trust's assets on behalf of its beneficiaries or on behalf of some object (such as a charity). ${ }^{35}$

This simply means that the trustee is not holding the assets of the trust for the benefit of the trust itself but to ensure that the beneficiaries of the trust benefit from the trust. The trustee performs his or her duties in relation to the trust in order for the beneficiary to benefit.

This is in contrast to retirement funds, where trustees in the board of trustees perform their duties to enhance the performance of the fund and not to advance the wishes or interests of the members of the fund. As far as trusts are concerned,

the trustee is appointed and accepts office to exercise fiduciary responsibility over property on behalf of and in the interests of another. ${ }^{36}$

The trustee of a trust owes fiduciary duties to the beneficiary of the trust. The 'trust' trustee's fiduciary duty is inherent in the relationship between the grantor, trustee, and beneficiary, under this duty. A trustee is obliged to administer the trust solely in the interest of the trust's beneficiaries.

Therefore it is imperative that the trustee must refrain from engaging in 'self-dealing' or anything that may be construed as an act that benefits the trustee in some way to the detriment of a trust beneficiary. ${ }^{37}$

33 Van der Westhuizen $v$ Van Sandwyk 19962 SA 490 (W) 495D.

34 Land and Agricultural Bank of South Africa v Parker 20052 SA 77 (SCA) para 10, where it was held that "except where statute provides otherwise, a trust is not a legal person..." as quoted in Hunter et al Pension Funds Act fn 118.

35 Geach Trusts 61.

36 Land and Agricultural Bank of South Africa v Parker 20052 SA 77 (SCA) para 20.

37 Edward Jones Trust Company 2008 www.edwardjones.com. $562 / 569$ 
A trustee must generally speaking avoid as far as possible a conflict between her personal interests and those of the beneficiaries. ${ }^{38}$

Having been entrusted with the duty of protecting the interest of the beneficiaries, the trustee is not supposed to make a secret profit at the beneficiaries' expense or to place himself in a position where his interests conflict with his duty to the beneficiaries. $^{39}$ In Doyle $v$ Board of Executors ${ }^{40}$ the court held that a trustee undoubtedly occupies a fiduciary office which imposes upon a trustee the duty of utmost good faith towards all beneficiaries, whether actual or potential. As far as trusts are concerned, the trustees owe fiduciary duty to the beneficiaries of the trust. However, the position is different with regard to retirement funds, which possess independent legal personality under South African law, as shown above.

As far as the fiduciary duties owed by the board of trustees to the fund are concerned, it has been correctly stated that "the applicable legal principles are the same as those which apply to directors of companies". ${ }^{41}$ In Fisheries Development Corporation of SA Ltd $v$ Jorgensen ${ }^{42}$ the court held that

the director's duty is to observe the utmost good faith towards the company, and in discharging that duty he is required to exercise an independent judgment and to take decisions according to the best interests of the company as his principal.

It was also held in Boulting $v$ Association of Cinematograph Television \& Allied Technicians $^{43}$ that:

Or take a nominee director, that is, a director of a company who is nominated by a large shareholder to represent his interests. There is nothing wrong in it. It is done every day. Nothing wrong, that is, so long as the director is left free to exercise his best judgment in the interests of the company which he serves. But if he is put upon terms that he is bound to act in the affairs of the company in accordance with the directions of his patron, it is beyond doubt unlawful.

38 Jowell v Bramwell-Jones 20003 SA 274 (SCA) para 16.

39 Robinson v Randfontein Estates Gold Mining Co Ltd 21921 AD 168 160e-i.

40 Doyle $v$ Board of Executors 19992 SA 805 (C) 813A-B.

41 PPWAWU National Provident Fund $v$ Chemical Energy Paper Printing Wood and Allied Workers Union 2007 ZAGPHC 146 para 25.

42 Fisheries Development Corporation of SA Ltd v Jorgensen 19804 SA 156 (W) 163D-F.

43 Boulting v Association of Cinematograph Television \& Allied Technicians 19632 QB 606, 626. 
The director of a company does not owe fiduciary duties to the shareholders of the company, nor is he or she obliged to be dictated to by their wishes. All that the director has to do is to utilise his talents to advance the interest of the company. The same applies to retirement funds. The board of trustees should seek to advance the objectives of the fund and not the interests of the members of the fund. The role of the directors of companies and the legal principles applicable thereto has been held to apply mutatis mutandis to the trustees of a pension fund. ${ }^{44}$ The essential requirement for the establishment of a fiduciary duty is that the trustees in the board of trustees must stand towards the fund in a position of confidence and utmost good faith. ${ }^{45}$

\section{Conclusion}

It cannot be disputed that the members of pension funds are amongst the major stakeholders in their respective funds and that they have interests vested therein. However, the board of trustees is not obliged to advance such interests. I submit that trade unions are in a better position to seek to advance members' interests. ${ }^{46}$ The board of trustees is accountable only to the fund and further owes fiduciary duties only to the fund it serves. It has been shown in this paper that as far as fiduciary duties are concerned, the principles of trust law are different from the principles of pensions law, and that it would not be ideal to apply such principles to pension funds; further, that the role of the board of trustees can be compared to that of the directors of companies. The pension fund itself is the owner of its assets, and its board members, like the directors of a company, must direct and control those assets in the interests of the pension fund. ${ }^{47}$ As far as trusts are concerned, it has been held that "the relationship between a trustee, and for that matter a beneficiary of a trust, is therefore, more real and direct than would be the case between a director or shareholder of a company". ${ }^{48}$ This simply means that a trustee of a trust

44 PPWAWU National Provident Fund $v$ Chemical Energy Paper Printing Wood and Allied Workers Union 2007 ZAGPHC 146 para 27.

45 Phillips v Fieldstone Africa (Pty) Ltd 20041 All SA 150 (SCA) 159e-g.

46 Hunter et al Pension Funds Act 163.

47 Hayton "Pension trustees" 1.

48 Harris $v$ Rees 20112 SA 294 (GSJ). 
manages the trust for the benefit of the beneficiaries, while on the other hand the director of the company manages the company for the benefit of the company. The latter position is also true for the board of trustees of pension funds, which manages the fund for the benefit only of the fund.

A fiduciary duty is a very high duty of care and it involves a high degree of trust and honesty. The duty basically involves an obligation to care for the financial affairs or wellbeing of the fund. This is a duty which the board of trustees owes only to the fund. However, the board of trustees does owe a duty of good faith towards the members of the fund. The duty of good faith means that the board of trustees should not without reasonable and proper cause conduct themselves in a manner calculated or likely to seriously prejudice the members of pension funds, for instance by making reckless investments leading to the fund's being unable to pay benefits to its members. The board of trustees should not act negligently when dealing with the affairs of the fund. The board needs to operate independently and lawfully within the boundaries of the rules of the fund and the PFA, even though at times it may exercise its discretion as outlined in the rules of the fund. Being loyal to the fund and executing its duties efficiently and effectively will result in the board's benefiting the members of the fund. The members of the board are therefore required to act with due care and diligence, to avoid conflict of interest with the fund, and to act with impartiality in respect of all members and beneficiaries of the fund. ${ }^{49}$

49 Section 7C PFA. 


\section{Bibliography}

Andrews 2004 SAAJ

Andrews JP "The Conversion of Members' Rights in South African Retirement Funds from Defined Benefits to Defined Contributions and the Statutory Apportionment of the Resulting Actuarial Surplus" 2004 SAAJ 1-52

Asher 2001 SAAJ

Asher A "The Appropriate Disposal of Retirement Fund Surpluses" 2001 SAAJ 1-33

Cameron et al South African Law of Trusts

Cameron E et al The South African Law of Trusts (Juta Cape Town 2002)

Du Toit 2007 Stell LR

Du Toit F "The Fiduciary Office of Trustee and the Protection of Contingent Trust Beneficiaries" 2007 Stell LR 469-482

Geach Trusts

Geach WD Trusts: Law and Practice (Juta Cape Town 2007)

George Analysis of South African Pension Fund Conversions

George DT Analysis of South African Pension Fund Conversions: 1980-2006;

Developing a Model for Dealing with Environmental Changes (DBL-thesis UNISA 2006)

Hayton "Pension trustees"

Hayton D "The Extent of Pension Trustees' Obligation in South Africa" in PLA Annual Conference 15-17 February 2004 Cape Town 1-14 
Hunter et al Pension Funds Act

Hunter $\mathrm{R}$ et al The Pension Funds Act: A Commentary on the Act, Regulations, Selected Notices, Directives and Circulars (Hunter Employee Benefits Law Johannesburg 2010)

Vivian "South African Insurance Markets"

Vivian RW "South African Insurance Markets" in Cummins D and Venard B (eds) Handbook of International Insurance Between Global Dynamics and Local Contingencies (Springer New York 2007)

\section{Register of case law}

Bellairs v Hodnett 19781 SA 1109 (A)

Boulting v Association of Cinematograph Television \& Allied Technicians 19632 QB 606

Caffin $v$ African Oxygen Limited Pension Fund Case Nos PFA/WE/14/98 \& PFA/WE/26/98

Doyle v Board of Executors 19992 SA 805 (C)

Ferguson v Sapref Pension Fund Case No PFA/WE/673/99/SM

Fisheries Development Corporation of SA Ltd v Jorgensen 19804 SA 156 (W)

Harris v Rees 20112 SA 294 (GSJ)

Hofer $v$ Kevitt 19962 SA 402 (C)

Isaacs v SAMA Pension Fund Case No PFA/WE/278/98/NJ

Johannesburg Municipality Pension Fund $v$ NCB Employee Benefits (Pty) Ltd

(Unpublished case) Case No 74/01

Jowell v Bramwell-Jones 20003 SA 274 (SCA)

Land and Agricultural Bank of South Africa v Parker 20052 SA 77 (SCA)

Mahlangu v Soweto City Council Pension Fund Case No PFA/GA/9384/2006/SM

Marais v Momentum Life Pension Fund Case No PFA/GA/1459/01/CN 2002

McDonald v Horn 19951 All ER 961 (CA)

Phillips v Fieldstone Africa (Pty) Ltd 20041 All SA 150 (SCA) 
PPWAWU National Provident Fund v Chemical Energy Paper Printing Wood and Allied Workers Union 2007 ZAGPHC 146

Registrar of Pension Funds v ICS Pension Fund 2010 ZASCA 63

Robinson v Randfontein Estates Gold Mining Co Ltd 21921 AD 168

Tex Corporation Provident Fund v Lorentz 19994 SA 884 (SCA)

Transvaal Cold Storage Co Ltd v Palmer 1904 TS 4

Volvo (Southern Africa) (Pty) Ltd v Yssel 20096 SA 531 (SCA)

Van der Westhuizen v Van Sandwyk 19962 SA 490 (W)

\section{Register of legislation}

Companies Act 71 of 2008

Financial Institutions (Protection of Funds) Act 28 of 2001

Pensions Fund Act 24 of 1956

Trust Property Control Act 57 of 1988

\section{Register of Internet sources}

Cheadle, Thompson and Haysom Attorneys Date Unknown www.naledi.org.za Cheadle, Thompson and Haysom Attorneys Date Unknown Accountability of Pension Fund Service Providers: The Role of Trustees www.naledi.org.za/index.php?option=com_rokdownloads\&view=file\&ltemid=2 67\&id=103:service-provider-accountability [date of use 30 May 2012]

Edward Jones Trust Company 2008 www.edwardjones.com

Edward Jones Trust Company 2008 Fundamental Duties of a Trustee: A Guide for Trustees in a Post-Uniform Trust Code World www.edwardjones.com/groups/ejw_content/documents/document/web043726 .pdf [date of use 10 Oct 2011] 
Hunter 2000 www.hunterlaw.co.za

Hunter R 2000 Retirement Funds: Case Law Update - Workshop 4, Labour Law Conference 19-21 July 2000 Durban www.hunterlaw.co.za/wpcontent/uploads/2011/04/4_2000-07-20-Retirement-Funds-Case-Law-..[date of use 10 Oct 2011]

Ikard 2006 privateaudio.homestead.com

Ikard FN Jr 2006 Trust Litigation and Defending a Trustee for Breach of Fiduciary Duty privateaudio.homestead.com/TrustLit.pdf [date of use 10 Oct 2011]

Liberty Corporate 2009 www.libertycorporate.co.za

Liberty Corporate 2009 The Fiduciary Duties of Retirement Fund Trustees www.libertycorporate.co.za/our-brochures/Documents/our-

brochures/fiduciary-duties-of-retirement-fund-trustees.pdf [date of use 2 Oct 2011]

Sanlam 2012 southafrica.smetoolkit.org

Sanlam 2012 Employee Benefits - Retirement southafrica.smetoolkit.org /sa/en/content/en/5049/Employee-benefits-retirement\# [date of use 30 May 2012]

\section{List of abbreviations}

PFA Pensions Fund Act 24 of 1956

SAAJ South African Actuarial Journal

Stell LR Stellenbosch Law Review 